\title{
Freedom of the Press, the Zimbabwean Situation Up to 2009
}

\section{Lungisani Moyo}

\author{
Department of Communication, University of Fort Hare, Private Bag X 1314, Alice 5700
}

Email: lungie06@gmail.com

\section{Dr. Osunkunle O. Oluyinka}

Department of Communication, University of Fort Hare

Email: oosunkunle@ufh.ac.za

Trevor Chabwinja

Department of Communication, University of Fort Hare, Bag X1314 Alice 5700

Email: tchabwinja@gmail.com

\section{Doi:10.5901/mjss.2014.v5n27p1543}

\begin{abstract}
The focus of this study was on the nature and operation of laws and regulations that were and are still being used to limit the freedom of the media in Zimbabwe. The focal point of this study was to examine the impact of media laws in Zimbabwe on the freedom of expression of its citizens. The study scrutinised media laws such as Access to Information and Protection of Privacy Act (AIPPA), the Public Order and Security Act (POSA) and the Broadcasting Services Act (BSA). The study focused mainly on the period before the amendment of the constitution ascended in 2013. The underpinning theoretical framework was informed by the Authoritarian, Libertarian and the Social Responsibility schools of thought. Questionnaires and in-depth interviews with selected key informants were the chief methods for data collection. Secondary data such as court cases, newspapers and some documents from organisations such as the UN, African Charter and Southern Africa Development Community (SADC) Protocol on Culture, Information and Sport were also consulted. Qualitative data was analysed using thematic content analysis while tables, graphs and charts which were interpreted and linked with processed qualitative data to come up with emerging trends and resolutions. The study revealed that the government is aware of the shortcomings in the regulations and laws relating to the media, but is not willing to make indisputable and inclusive reforms. These laws are found to be impacting negatively on freedom of expression on citizens especially journalists and their media houses. It was clear from the findings that media houses in Zimbabwe are susceptible to these laws and as a result, some media houses such as Daily news, Tribune and Capital radio have been forced to close. This goes on to validate that the current media in Zimbabwe is not free and are found to be adjacent to global norms such as the SADC Protocol on Culture, Information and Sport, the Universal Declaration of Human Rights Article 19, the African Charter Article 9, and African Convention of Human and Peoples' Rights (ACHPR) which advocates for freedom of the media and expression. The study concluded that there is no freedom of expression in media legislation as has been witnessed from the findings of the study. The study then recommended crafting of new laws which promote freedom of expression of the citizens of Zimbabwe.
\end{abstract}

Keywords: human rights, media legislation, freedom of expression

\section{Introduction}

The media in Zimbabwe has witnessed varying amounts of control by successive governments. However, in recent years they have come under tight restriction by the ruling government, particularly during the growing economic and political crisis in the country. The Zimbabwean constitution promotes freedom of the media and expression; however this is hampered by interference of strict laws such as the Access to Information and Protection of Privacy Act (AIPPA), the Public Order and Security Act (POSA) and the Broadcasting Services Act (BSA), this resulted in many papers being banned and the remaining ones had a lot of blank patches as a result of articles removed due to their failure to meet the censorship standards (Mudzengi et al, 2003).

Zimbabwe with the changes in its name at different times: Southern Rhodesia, Rhodesia, Zimbabwe-Rhodesia, and finally Zimbabwe in 1980 never really experienced genuinely free media (Melber, 2004). At independence in 1980, the new government adopted the RBSA of 1973 and renamed it the Zimbabwe Broadcasting Act (ZBA), 12/1980. It was 
easy and logical for the new government to take over the electronic media because under Rhodesian laws the broadcasting outlets were already under government control, although there was a political leadership shift since the country had gained its independence from colonial minority rule; the Act remained predominantly the same (Chirume, 2005). The Zimbabwe Broadcasting Corporation (ZBC) only transformed its hegemonic position from protecting colonial supremacy to endorse black political power after independence (MISA, 2001). Issues pertaining to black empowerment, education and health for all became key issues of concern for the new government as a result revising the colonial legislation was not an issue requiring any major concern at that time (Chari et al, 2003).

\section{Literature Review}

Due to repressive media laws on publishing, literature in this field is limited and the study therefore relied on what was available, and more general literature. The study examines press freedom in Zimbabwe.

\subsection{Theoretical framework}

A distillation of the literature leads one to come up with the following theoretical frameworks. One approach would be to use McQuail's Normative Theories which are mainly concerned with restrictions (and freedom of) media in various situations and how this impacts on the functioning of the media in the society. This was premised on the 1950's study of the different press systems in the world whose results have been updated in 1983 and 2005 (Siebert, Peterson and Schramm: 1956). Initially, they developed three theories that relate to the media (press), which were later adopted as a yardstick for the measurement of the freedom of expression the world over. These are the Authoritarian, Libertarian and the Social Responsibility theories.

\subsubsection{Authoritarian Theory}

According to McQuail (1987), the authoritarian state system requires direct governmental control of the mass media. The media in an authoritarian system is not allowed to print or broadcast anything, which is viewed as undermining the authority of the government. The fundamental assumption of the authoritarian system is that the government is infallible. Media professionals are therefore not allowed to exercise any operational independence within their media organisations. Foreign media houses and personnel are subordinate to the established authority and the repressive legislation restricts the operations of such media organisations.

Under authoritarianism the main function of the media is to publicise and propagandise the government's ideology and actions. In other words the press is an instrument and mouth piece of the government. The Authoritarian Theory mainly applies in dictatorial societies. It also surfaces in less Authoritarian Societies when the freedom of the press may be found to be conflicting with the interest of the state or society, for example when there is a threat of terrorism or in times of war.

Authoritarianism can also be exercised with regard to one media in contrast with other media. In some countries, for instance, the electronic media is subjected to greater control than the print media. This is so because the autocratic governments believe that the electronic media is easily accessible and reaches out to greater population than the print media. The Authoritarian Theory is not merely of historical or descriptive importance or simply an extra ordinary deviation from established democratic norms. It continues to justify government suppression of the media (Roelofse, 1996).

According to Roelofse (1996), some of the most significant communication and political events in the past century took place in authoritarian societies. The fascism (the philosophy and practice of the absolute power of the state in subservience of the individual) found in Europe in the 1900s in Adolf Hitler's Germany, Benito Mussolini's Italy, General Francisco Franco's Spain, in communist regime in Eastern Europe and elsewhere, South Africa's apartheid regime from 1948-1994 and in many post- independence African countries, was and in many cases rooted in authoritarianism and totalitarianism. Authoritarianism gave much freedom to the rulers, little or no freedom to the ruled, and defined freedom of expression as vested in the state.

In the Zimbabwean context, the government exercises absolute power over the media by applying laws such as AIPPA, POSA and BSA in order to suppress the media; which is generally seen as being authoritarian. For instance, a number of journalists were arrested for violating AIPPA, while over 70 journalists, all from private media houses were threatened since the promulgation of the law (The Daily News in exile, 2007.) The most significant attack on the private media took place in January 2001, when a bomb explosion wrecked the printing press of the Daily News in Harare- only hours after 
the former Minister of information and Publicity had publicly threatened the paper. The publication was subsequently forced to close down by the government rendering many journalists jobless. Furthermore the impact of the attack on The Daily news production was predictably severe. Although it took place more than a year before the presidential elections, the bombing continued to have a serious impact on the capacity of the country's largest daily paper to get the news to its readers. (The Daily News in Exile Thursday 3, May, 2007).

\subsubsection{Libertarian Theory}

In contrast to the Authoritarian theory, the Libertarian theory is premised on the idea that the individual should be free to publish whatever he or she likes. In the Libertarian system, attacks on the government policies are fully accepted and even encouraged. Moreover, there should be no restrictions on import or export of media messages across the frontiers. Furthermore, journalists and media professionals ought to have full autonomy within the media.

According to the Libertarian Theory, people are rationale beings capable of distinguishing between the truth and falsehood and between the good and the evil. The search for the truth is regarded as an inalienable natural right. In terms of these beliefs the media is seen as the source of information and a platform for the expression of divergent opinions, informing people about government affairs and other issues and enabling them to monitor their government and from their own ideas about policy. The media should be free from government control and government influence, and there must be a free market for ideas and information (Roelofse, 1996). The USA, Canada and Britain had this type of media for approximately 200 years, closely followed by mainland European countries such a Netherlands and France. The media has been encouraged to act as the fourth estate along the legislative, executive and judiciary authorities in the government process (McQuail, 1987).

However the application of the idea of a free media is not simple as McQuail (1987) observes:

The question of whether a free media is an end in its self, a means to an end, or absolute right has never been settled. Once freedom has been abused, it is no longer freedom and should be restricted. Absolute freedom is in fact anarchy. Libertarian societies therefore all more or less agree ... that freedom of the individual is defined and thus constrained by the freedom of other individuals.

\subsubsection{The Social Responsibility Theory}

The Social Responsibility Theory is an outgrowth of the Libertarian Theory. However, social responsibility goes beyond "objective" reporting to "interpretive" reporting. A truthful, complete account of the news is not necessarily enough today. "It is no longer enough to report the fact truthfully. It is now necessary to report the truth about the fact." (Commission on the Freedom of the Press 1940). Today's complex world often necessitates analysis, explanation, and interpretation of news.

As the Commission stated in 1940: "The Social Responsibility theory does not deny the rationality of man, although it puts far less confidence in it than the libertarian theory, but it does seem to deny that man is innately motivated to search for truth and to accept it as his guide." Under the Social Responsibility Theory, man is viewed not so much as irrational but is capable of using his reason though he loathes doing so. If man is to remain free, he must live by reason instead of passively accepting what he sees, hears, and feels. Therefore, the more alert elements of the community must goad him into the exercise of his reason. Without such goading, man is not likely to be moved to seek the truth. The lethargy which keeps him from using his gift of reason extends to all public discussion. Man's aim is not to find truth but to satisfy his immediate needs and desires. It is the press, therefore, that must be the "more alert element" and keep the public informed, for an informed populace is the cornerstone of democracy.

Today's large media conglomerates, however, may not function naturally as a public forum, where all ideas are shared and available. "The owners and managers of the press determine which persons, which facts, which versions of these facts, shall reach the public," writes Boyd-barret and Newbold (1995).

In the same light, (McQuail, 1987) warn that the power and near monopoly position of the media impose an obligation on the media to be socially responsible, to see that all sides are fairly represented and that the public has enough information to decide; and that if the media do not take on themselves such responsibility it may be necessary for some other agency of the public to enforce it. The Canons of Journalism adopted by the American Society of Newspaper Editors addresses these same obligations when it calls on newspapers to practice responsibility to the general welfare, sincerity, truthfulness, impartiality, fair play, decency, and respect for the individual's privacy.

McQuail, (1987) also note that "freedom of expression under the Social Responsibility Theory is not an absolute right, as under pure Libertarian Theory. One's right to free expression must be balanced against the private rights of 
others and against vital social interests." However, it would not be socially responsible, for example, to report how a terrorist, using some new method, evaded security measures and smuggled a bomb onto a commercial airline.

Exponents of this theory attempt to reconcile the ideas of freedom and independence with responsibility towards society (Roelofse, 1996). According to MacQuail (1987), the social responsibility theory is based on the following premises:

(a) the media should support democratic political principles;

(b) the media is under an obligation to create a forum for different viewpoints;

(c) the independence of the media should be emphasised in relation to their responsibility towards society; and that

(d) the media should meet globally acceptable standards.

In view of the three theories to media legislation discussed above, this study adopted the Libertarian Theory as an analytical tool, in the sense that, it advocated for the freedom of the media from any external censorship.

\subsection{Media Legislation: A Conceptual Analysis}

Although Zimbabwe has always had an array of legislations which have stifled freedom of expression from the UDI era to independence, in 2002 further media repression was reinforced. Government brought into effect laws such as POSA, AIPPA, BSA and the Private Voluntary Organisations Act (PVOA).

AIPPA governs the operations and general conduct of the media in a way that leaves media with little breathing space. AIPPA was passed by parliament of Zimbabwe on 31 January 2002 and signed into law on 15 March 2002. Since its enactment, Zimbabwean journalists and media practitioners have continued to endure harassment and threats as the media landscape continued to shrink following the closure of privately owned newspapers. This left the media with little space to fulfil its public watchdog status as the fourth estate, which plays an adversarial role against government. Citizens have thus been deprived of their right to freedom of expression and the right to access information. AIPPA provides for access to information held by public bodies [Section 78], but it is up to the heads of these bodies to decide what they will and will not release "in the public interest". Ironically, it is not the public that decides what is in their interest but the government officials. The Act allows public officials to hold information for thirty days after a request for information is made, which may be impractical for journalists (Feltoe, 2003).

AIPPA's trail of destruction, both emotional and physical, can be traced to its enactment in 2002 and the plethora of arrest, intimidation, harassment and measures of control which immediately followed. These have been directed at media workers of all sorts - journalists, photographers, vendors and even newsroom drivers - as well as media outlets, in particular Independent print Media. Media space in Zimbabwe has continuously shrunk since the closure of Associated Newspapers of Zimbabwe (ANZ), publishers of the mass circulating, The Daily News and The Daily News on Sunday, on 12 September 2003. The government's determination to maintain AIPPA as its shield against criticism and exposure of corruption in higher offices came in the wake of the closure of the African Tribune Newspapers in February 2005 (Thakurta: 2009).

POSA was promulgated in 2002, and was meant to repeal LOMA but in effect; POSA may appear as a rereworded version of LOMA. POSA contains provisions that curtail freedom of expression. POSA re-introduces provisions of the 1964 Preservation of Constitutional Government Act, (repealed in 1999), which the Rhodesian government used to suppress nationalist movements such as Zimbabwe African People's Union (ZAPU) and ZANU PF. The new provision carries a penalty of twenty years imprisonment without the option of a fine for deliberately publishing falsehoods. These falsehoods may be those negatively reflecting on the government or those in authority

Whilst the Constitution proclaims the right to freedom of expression, association and assembly, these rights may be limited in the interests of defence, public order or public safety. Section 15 of POSA deals with publishing or communicating "false statements" considered prejudicial to the state. Section 15(1) of POSA makes it a criminal offence for a person inside or outside the country to communicate a statement that is wholly or materially false, and which; promotes public disorder or endangers public safety, adversely affects the defence or economic interests of Zimbabwe, undermines public confidence in the security forces and disrupts any essential service. Proof that the statement was intended to cause any of the above is enough to bring about a conviction, which carries a fine and or a five year prison sentence. The law applies not only to mass media, but also to reports produced by businesses and other civil society organizations. This false statements provision is a re-enactment of section 50 of LOMA; it however takes into account the Supreme Court's judgment in Chavunduka \& Anor -V- Minister of Home Affairs \& Anor, in which section 50 of LOMA was ruled to be in contravention of Section 20 of the Zimbabwean Constitution (Pottie, 2000)

POSA's section 15 (2) prohibits the publication of a statement by a person who knows the statement to be false, or 
who does not have reasonable grounds for believing the statement to be true, if the statement gives rise to one of the four consequences listed above. By going beyond defence, public safety, public order and the country's economic interests, the subsection exceeds the permissible limits set out under section 61 of the Constitution. This offence is punishable even where the accused person thought their statement was true, if the court finds that the person did not have reasonable grounds for believing the statement to be true. It is submitted that the effect of this provision is to subject media houses and journalists into a self censorship exercise before publishing anything. This inevitably impedes on the right to freedom of expression. The public in such a situation are not guaranteed of balanced reporting. Increasingly the authorities have used Section 15 of the Act against the private media, as well as civil society leaders and those perceived to support the opposition. However, in most instances these charges have been dropped on the advice of the Attorney General's office (Pottie, 2000). The on-going threat of the use of POSA doubtless has a chilling effect on the government's critics and the media in particular.

Section 16 (2) of POSA deals with issues of undermining authority of, or insulting President, and is taken from section 46 of LOMA. Section 16:

(a) prohibits the making, publicly and intentionally, of any false statement (including an act or gesture) about or concerning the President or Acting President if the person knows or realizes that there is a risk or possibility of engendering feelings of hostility towards or causing hatred, contempt or ridicule of the President or Acting President, whether in their official or personal capacity.

(b) It is also an offence to make abusive, indecent, obscene or false statements about the President.

In terms of section 24 of POSA, anyone organising a public gathering has to give the police at least four day notice. Many police stations, whether deliberately or by mistake, interpret this provision to mean that the organiser must apply for, and obtain police permission to hold a gathering, whereas the law simply requires notification. The Police relying on this provision have broken up many gatherings. The impact on media freedom is self evident. It inevitably follows that each time such gatherings are either disbanded or disallowed on vague grounds the media's role to report on such activities is also interfered with. It is respectfully submitted that this provision is in consistent with the Constitution (lbid).

The BSA ${ }^{1}$ was promulgated following attempts by Capital Radio to go on air in 2000. Capital Radio was a privately owned radio station that was already illegally broadcasting into Zimbabwe from outside the country after being denied permission to operate legally (Weza, 2001). BSA establishes the Broadcasting Authority of Zimbabwe (BAZ), which grants broadcasting licenses. As with MIC (now ZMC), the Minister appoints the members of BAZ, which however, has yet to license a private or community broadcaster. Under BSA, it is an offence to broadcast without a license, and only citizens ordinarily resident in Zimbabwe, or a body whose controlling interest are held in Zimbabwe, can only apply for a license. Contravention of the law attracts a fine and/or two years imprisonment. The BSA further requires a broadcaster to reserve, free of charge, one hour of programming a week for the Government to explain its policies. At least $75 \%$ of a broadcaster's programming must be produced locally or elsewhere in Africa. (MISA, 2001) Whilst the need to have a registering authority for broadcasters is widely acknowledged, however what is dangerous and inimical to a democratic society is to repose in the registering authority ill defined powers on which it can refuse the registration of media houses.

It is in this respect that the BSA is incongruent with the constitution as it has given enormous power to the authorities to refuse registration of private radio stations and maintaining the monopoly of ZBC long after it had been held to be unconstitutional (a practical example is the case of Capital Radio \& Anor .v. Min Of Information).

POSA, AIPPA and BSA violate fundamental human rights enshrined in the Zimbabwe Bill of rights as well as African Convention of Human and Peoples' Rights (ACHPR), Southern Africa Development Community (SADC) Protocol on Culture, Information and Sport and many other instruments to which Zimbabwe is a party to. POSA, AIPPA and BSA violate the freedoms enshrined in Article 9 of the Charter, in that they impede on general public's right to receive information as this is subject to regulation by the executive and state's bureaucracy. The African Charter Article 9 states that:

"Every individual shall have the right to receive information. Every individual have right to express and disseminate his opinions within the law"

1 The Broadcasting Services Amendment Act, 2001 is an Act which provided for a state monopoly over all broadcasting (radio and television) in Zimbabwe. 


\section{Research Methodology}

\subsection{Participants}

Qualitative and quantitative approaches were adopted, a sample size of 55 participants, which comprised of (17) University Zimbabwe Media Students, (16) Media Analysts and (17) Polytechnic Media students (2) Editors, (1) journalist and (2) human rights lawyers since they had in-depth knowledge in media laws in Zimbabwe was adopted. There were 600 participants as the total population from which only $10 \%$ was used as the sample due limited time and resources.

\subsection{Instrument}

The instruments that were used for data collection in this study were documents, questionnaires and In-depth interviews. Documents such as the African Charter and the Universal Declaration of Human Rights were used. The other data collection instrument which was used to collect information from the respondents was the self - administered questionnaire. This study also utilised interviews in the form of one-to-one structured interviews for primary data collection

\section{Findings and Discussion}

The knowledge of the media laws

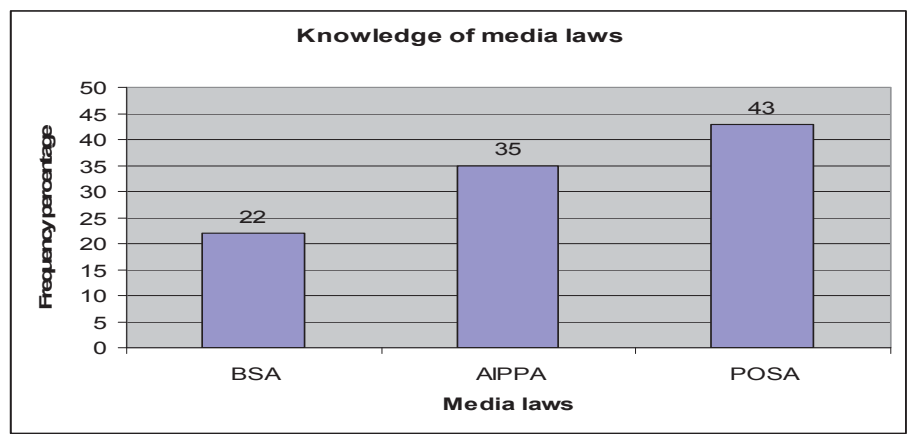

Fig 1: Knowledge about media laws in Zimbabwe

Respondents were asked their awareness of the current media laws in Zimbabwe that is, the BSA, POSA and AIPPA. $22 \%$ of the respondents were aware of the BSA because the law restricted them to watch one channel which is ZBC TV. $43 \%$ of the respondents were also aware of POSA in the sense that it is a law that empowers the police to disrupt gatherings or anyone organising a public gathering. At least a four-day notice should be given to the police before any gathering. The study established that there was a misinterpretation of this law by the police who deliberately or by mistake, interpreted this provision to mean that the organiser must apply for, and obtain police permission to hold a gathering, whereas the law simply requires notification. This loophole is often exploited by politically biased officers to behave like political bullies.

The study found out that the police relying on this provision have broken up many gatherings. The impact on media freedom is self-evident. It inevitably follows that each time such gatherings were either disbanded or disallowed on vague grounds. The media's role to report on such activities is also interfered with. The study established that this provision is inconsistent with the constitution. $35 \%$ of the participants were also aware of the AIPPA as a law that governs the operations and general conduct of the media in a way that leaves the media with little breathing space. The study found out that enforcing on its ambiguity made it difficult to reconcile the freedom of access to information with the freedom to protection and privacy of private information. Freedom of association is thus violated.

These findings refute what Khupe (2009) said about the media laws, during an interview with the Zimbabwe Independent press 07 May 2009, that although it was a general perception that the existing media laws were oppressive, there were sections that were good, he stated as follows:

"It's my view that current media laws in Zimbabwe are restrictive, but there are some sections which are good for media operations and people turn a blind eye on them. 
For example POSA's section 15 (2) prohibits the publication of a statement by a person who knows the statement to be false, or who does not have reasonable grounds for believing the statement to be true. By going beyond defence, public safety, public order and the country's economic interests, the subsection exceeds the permissible limits set out under section 20(2) of the Constitution."

The three media laws: BSA, AIPPA, and POSA are not the only media-related laws in Zimbabwe but they are the ones that have been more quoted as clashing with freedom of expression than any other, hence the study mainly focused on these three laws. These laws were generally believed to be too general, vague and ambiguous to stand the test of legal litigation according to some of the respondents in the follow-up interviews. Some of the respondents believed that they were sectarian rather than national in that they protected certain sections of the community against others.

Some journalists argue that because of the interference of these laws, they are forced to report with bias towards certain sections privileged for fear of persecution under any of these 'draconian' laws. This notion was further supported by the Authoritarian theory which applies in dictatorial societies such as Zimbabwe. It also surfaces in less Authoritarian Societies when the freedom of the press may be presented as conflicting with the interest of the state or society, for example when there is a danger of terrorism or in times of war. However in follow up interviews the respondents were advocating for media freedom, which is supported by Libertarian theory. The libertarian theory is premised on the idea that the individual should be free to publish whatever he or she likes. In the Libertarian system, attacks on the government policies are fully accepted and even encouraged. Moreover, there should be no restrictions on import or export of media messages across the frontiers.

Fig 1 indicates familiarity levels of participants with these laws. This can be used to measure the extent of their knowledge of their rights in the context of these media laws. Some of the respondents who were aware of such laws were more likely to understand how they impact on their freedoms.

Some of the respondents who were more informed about media laws expressed misgivings on the media laws such as the POSA which does not allow gatherings for any reason and that people should give a four-day notice to the police before gathering. This according to the respondents negatively impacted on their freedom, thus the respondents recommended that such laws should be repealed. They further recommended that it was a waste of time and resources to amend such laws since they had the same negative effect on people's freedom of expression in the media.

This recommendation also corresponds with what was said by a Member of Parliament, during an interview with the Zimbabwe Independent press 07 May 2009, that:

There is need for media reforms in Zimbabwe. It's my view that there is a real need for reforms in the media. .......Zimbabwe has the right to have a free media space.

Opinion on whether Media in Zimbabwe is free to air its views.

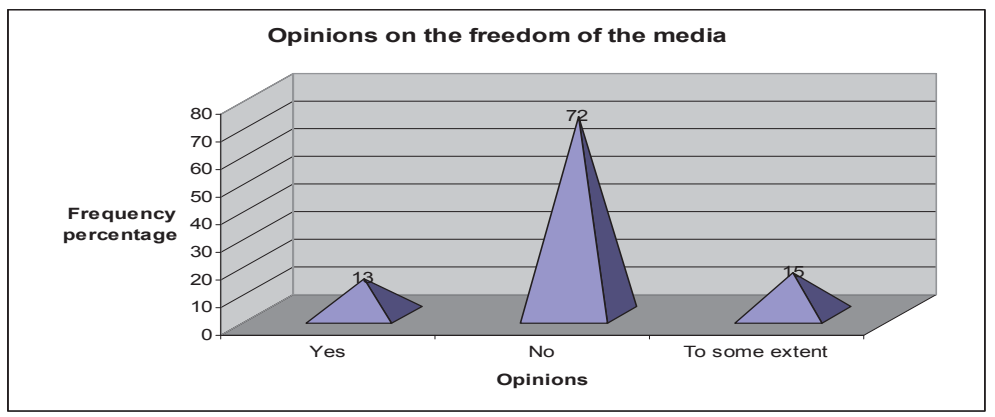

Fig 2: Opinion on whether Media in Zimbabwe is free to air its views

Fifteen percent (15\%) of the total respondents pointed out that to some extent the media laws were free to those who had access to them, but were also biased on political basis. $72 \%$ of the total respondents said that the media was not free to air its views in Zimbabwe, because the laws that were currently in place deprived them of certain information they wanted to hear, especially on political issues.

In follow -up interviews the respondents pointed out the fact that some journalists were arrested, some tortured and some killed so as to protect sensitive information from being heard. Those respondents were of the view that the Media in Zimbabwe was not free because those who formulated and implemented the laws were selected on political 
grounds to suppress opponents in the political sphere. They further complained that some matters could not be commented on freely and also that the government had failed to repeal repressive legislation such as POSA and the AIPPA and the BSA which were "inimical to the holding of free and fair elections".

However $13 \%$ of the total respondents said that the media is free to air its views because of the availability of different media spheres opposing the state run media. They further pointed that the media is free as was seen during the run off to the elections where all the political parties were given the platform to reach out to the voters through the use of media.

Opinion on whether current media laws in Zimbabwe allow for media freedom

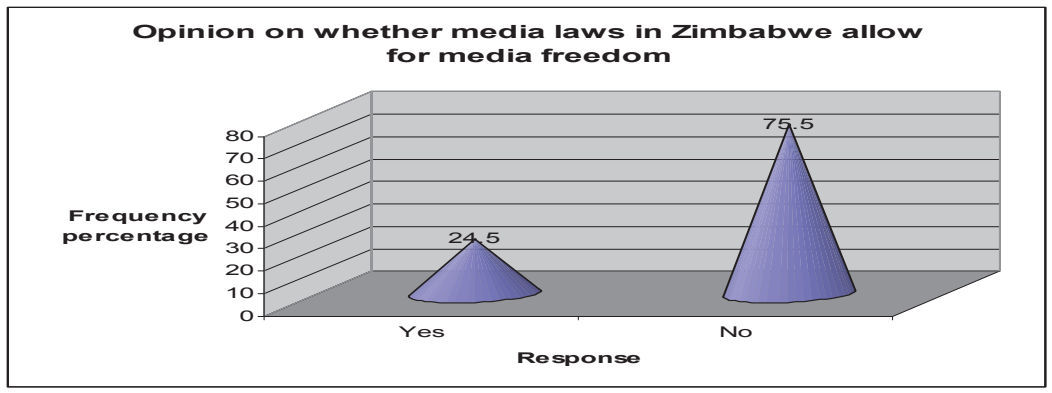

Fig 5.11: Opinion on whether current media laws in Zimbabwe allow for media freedom

Respondents were asked whether current media laws in Zimbabwe allow for media freedom, $75.5 \%$ of the participants agreed that the media laws in Zimbabwe do not allow for media freedom, because they hinder freedom of expression. $24.5 \%$ of the participants said the media laws in Zimbabwe allow for media freedom and this is due to the fact that most of them were aligned to ZANU PF. The general feeling was that media laws in Zimbabwe did not allow media freedom at all as they were biased because they were crafted to serve political interests of a single party and very few individuals.

The above findings disputes with what the European Commissioner to Zimbabwe said during an interview with the Herald of 17 September 2010. The Commissioner acknowledged the existence of a free Press in Zimbabwe. He also said that

"I have been in this country for the past eight days and what I can tell you is that there is a Press that is free. "You can read newspapers in this country and have a feeling of independent information".

However there were mixed feelings from those interviewed, some of the participants did not acknowledge that the current Constitution allows for freedom of expression because it is silent on the freedom of the press though others think the media is free. One Editor argued that,

"...... though freedom of expression is guaranteed in the Constitution of Zimbabwe, the legislation governing the media in Zimbabwe is fragmented, that is, some of the provisions of the media laws are found in security legislation."

This shows that there is no freedom of expression as observed by the Editor.

One journalist from the private newspaper said

".....media laws in Zimbabwe cannot be incongruent with the Constitution because the Constitution is void. The Constitution was drafted by concerned parties, that is, the British government, ZANU and ZAPU during the Lancaster House agreement. Even the current process of media reforms was initiated by talks from the three parties (The ruling ZANU PF, MDC-T and MDC-M) and the same talks centred on the issue of a new Constitution for Zimbabwe."

Therefore the reforms which are taking place are certainly not in congruent with the Constitution and even the current Constitution does not call for freedom of expression.

A journalist from an independent paper said that,

"the media at the present moment is polarised into the state controlled and the private media. The polarisation has affected how people get accurate, truthful and unbiased information. The information that has been reported by the private media has been termed Western ideology. In those circumstances it is difficult to get the truth and participate in 
politics from an informed position."

The study observed that, no opposition or dissenting opinions were tolerated. In response to this, opposition political formations in cohorts with western powers and big corporate set up private media houses and pirate broadcasting stations both in Zimbabwe and neighbouring countries. These opposing sides have been combated to paint the 'Truth' from their own perspective. The study observed that people read the government owned newspapers more often because the government media was cheaper and easily accessible whilst the private media comes at a cost.

One of The human rights lawyer further went on to say that:

"....there were some parts of the country in which there is a defector embargo on private newspapers. The obvious effect is that people in such areas have only a single market place of ideas. Coincidentally the ZANU PF party has recorded significant victories in such areas during elections. At some point in time reading newspapers from private media houses was synonymous with allegiance to oppositional politics for which one could lose life and or limb. All this has impacted on how people participate in politics. Participating in politics requires making certain defined and informed decisions, and where one is denied access to the truth, the process becomes difficult and at times costly"

Some of The respondents pointed that the government should remove restrictive laws such as AIPPA, POSA and BSA to give more waves to the private media that can save the interests of the people not the government only. Removal of restrictive laws may also improve accuracy of information, as journalists will be able to report freely without any hindrance from the state. This was shown when one of the interviewees said:

"Are you not wired?" said one of the journalists from the independent news paper. "I don't trust people who talk about AIPPA and POSA because you end up victimising us and I do not want to stand a chance of spending a night in your rotten prison cells. However, the truth of the matter, freedom of the press should be enshrined in the Constitution while bad laws such as POSA, AIPPA, Interception of Communication Act and other bad laws should be repealed." The journalist also adds that, "... of course the government should set up statutory bodies to control the media but this must be done in such a way that the freedoms of individuals are not infringed. In fact government efforts should be corroborated by self-regulatory mechanisms within the media".

A human rights lawyer also said:

"... the most important thing would not only be to ensure there is freedom of expression but also freedom after expression."

As the former Minister of Justice once said:

"I might have freedom to express myself but I am not sure if I will remain free after that expression".

The solution is both political and legal. Because any changes to the law which lack political will, will be nothing more than deception. There is an urgent need to depoliticise public institutions such as ZBC and also develop a culture of human rights in which people are not only free but prepared to ask and fight for their rights and also to be accountable. Freedom should always be accompanied by responsibility.

The human rights lawyer also added that

"On the legal front there is need to remove government monopoly on the electronic and print media and ensure that mechanisms for registration of private players are simple, transparent and democratic. Further, such private players are also afforded the protection of the law".

One of the human rights lawyers recommended that self-regulation of journalists is encouraged just like other professionals like lawyers and accountants.

She further recommended that:

The government desires registration to keep the media in check as there is always the constant threats of either deregistration or refusal to entertain applications of perceived government opponents and this is inconsistent with open democracy. Further AIPPA ensures that access to information comes at a high premium; it is possible that a party might wait for up to ninety days before accessing information from the public bodies and in essence one would have been denied his right within a reasonable time and this provision is unconstitutional. 


\title{
5. Conclusion
}

\begin{abstract}
Although there have been notable changes to the constitution with regards to freedom of the press, on the ground the situation is still as before the amendment. this is largely because there is a disconnect between the new constitution and the legal instruments in place. The Zimbabwean parliament has not done anything notable to align the legislative framework with the new constitution. Hence there are still arrests and victimisation of media personnel (journalists and editors)
\end{abstract}

It is evident from the findings that political institutions in Zimbabwe are fragile in the absence of democratic political culture. Respondents showed considerable scepticism about significant changes without having political consensus. The lack of any consensual model of democracy and the political intolerance reinforce this fragility. Freedom of the media is being affected by the presence of hostile politics, media regulations and laws. Since partisan conflict is intense, it is therefore difficult for the partisan media to be effective and objective in expressing public opinion.

Laws such as AIPPA have been undermining freedom of expression in Zimbabwe by promoting excessive government control over the independent media as well as intimidation of media personnel. Dozens of journalists suffered direct legal harassment, mostly in the form of short-term detentions, thereby impacting negatively on the profession as a whole. The closing down of the space for freedom of expression in Zimbabwe is part of a clear strategy by government to continue to muzzle the press and harass its personnel. The whole framework of repressive legislation, that is the BSA, POSA and AIPPA has been carefully crafted to achieve precisely these ends. These laws are quite clearly in serious breach of the right to freedom of expression as guaranteed under international law in a number of key ways. These laws significantly fail to strike a balance between the legitimate interests of the State, for example in preserving national security and public order, and the rights to freedom of expression and democracy.

\section{References}

Boyd-barret $\mathrm{O}$ and Newbold c ed. (1995) Approaches to media: A Reader Arnold, London.

Chirume, C. 2005. The Politics of Media Regulation: A study of the origins of AIPPA 2001. An unpublished Masters Dissertation for the Partial Fulfilment of MSSC in Communication, University of Zimbabwe. University Press.

Daily News in Exile 2007: Available at: http://www.zimbabwejournalists.com/uploaddocs/Daily_News_in_Exile_2007_for_websites pdf [Accessed: 23 August 2013].

McQuail, D 1987 (second edition) Mass Communication Theory: An introduction: Sage publications. London.

Melber, H (e.d). 2004 Media, Public Discourse and Political contestation in Zimbabwe: The Nordic African Institute.

MISA- Zimbabwe 2009. Repressive Media Law (AIPPA): Available at: http://www.misa.org/cgi-bin/viewnews.cgi?category=2\&id=113705 4440 [Accessed: 30 October 2013].

Mudzengi, E., Gunduza, M.C \& Nyakupinda, D.2003. Radio and Television studies. Harare, the Zimbabwe Open University.

Pottie, d. 2000.Zimbabwe: Constitutional Referendum in Zimbabwe. Harare, Zimbabwe.

Thakurta, PG (2009) Media Ethics: Truth, Fairness and Objectivity, Oxford, Oxford.

Roelofse, K. 1996. The history of the South African press, an introduction to communication- course book5: Journalism, press and radio studies, edited by L.M. Oosthuizen Kenywyn: Juta: 66-118.

Siebert, F., Peterson, T., \& Schramm, W. (1956). Four Theories of the Press. Urbana: University of Illinois Press.

Weza, S. 2001. Zimbabwean media in crisis: issues and challenges Harare: Collage Press. 